\title{
Estimation of particulate organic nitrates from thermodenuder-aerosol mass spectrometer measurements in the North China Plain
}

\author{
Weiqi Xu ${ }^{1}$, Masayuki Takeuchi ${ }^{2}$, Chun Chen ${ }^{1,3}$, Yanmei Qiu ${ }^{1,3}$, Conghui Xie ${ }^{1,3, a}$, Wanyun $\mathrm{Xu}^{4}$, Nan $\mathrm{Ma}^{5}$, \\ Douglas R. Worsnop ${ }^{6}$, Nga Lee $\mathbf{N g}^{2,7,8}$, and Yele Sun ${ }^{1,3,9}$ \\ ${ }^{1}$ State Key Laboratory of Atmospheric Boundary Layer Physics and Atmospheric Chemistry, \\ Institute of Atmospheric Physics, Chinese Academy of Sciences, Beijing 100029, China \\ ${ }^{2}$ School of Civil and Environmental Engineering, Georgia Institute of Technology, Atlanta, GA 30332, USA \\ ${ }^{3}$ College of Earth and Planetary Sciences, University of Chinese Academy of Sciences, Beijing 100049, China \\ ${ }^{4}$ State Key Laboratory of Severe Weather \& Key Laboratory for Atmospheric Chemistry, Institute of Atmospheric \\ Composition, Chinese Academy of Meteorological Sciences, Beijing 100081, China \\ ${ }^{5}$ Institute for Environmental and Climate Research, Jinan University, Guangzhou 511443, China \\ ${ }^{6}$ Aerodyne Research Inc., Billerica, MA 01821, USA \\ ${ }^{7}$ School of Earth and Atmospheric Sciences, Georgia Institute of Technology, Atlanta, GA 30332, USA \\ ${ }^{8}$ School of Chemical and Biomolecular Engineering, Georgia Institute of Technology, Atlanta, GA 30332, USA \\ ${ }^{9}$ Center for Excellence in Regional Atmospheric Environment, Institute of Urban Environment, \\ Chinese Academy of Sciences, Xiamen 361021, China \\ ${ }^{a}$ now at: State Key Joint Laboratory of Environmental Simulation and Pollution Control, College of Environmental \\ Sciences and Engineering, Peking University, Beijing 100871, China
}

Correspondence: Yele Sun (sunyele@mail.iap.ac.cn) and Nga Lee Ng (ng@ chbe.gatech.edu)

Received: 1 December 2020 - Discussion started: 28 December 2020

Revised: 19 April 2021 - Accepted: 21 April 2021 - Published: 21 May 2021

\begin{abstract}
Particulate organic nitrates (pON) are an important component of secondary organic aerosol in biogenicemission-dominant environments and play a critical role in $\mathrm{NO}_{x}$ cycles. However, estimation of pON has been a challenge in polluted environments, e.g., North China Plain, with high concentrations of inorganic nitrate and $\mathrm{NO}_{x}$. Here we developed a method for estimation of pON from the measurements of high-resolution aerosol mass spectrometer coupled with a thermodenuder based on the volatility differences between inorganic nitrate and pON. The results generally correlated well with those estimated from positive matrix factorization of combined organic and inorganic mass spectra and from the ratio of $\mathrm{NO}^{+}$to $\mathrm{NO}_{2}^{+}\left(\mathrm{NO}_{x}^{+}\right.$ratio), yet they had improvements in reducing negative values due to the influences of high concentration of inorganic nitrate and constant $\mathrm{NO}_{x}^{+}$ratio of organic nitrates $\left(R_{\mathrm{ON}}\right)$. By applying this approach to the measurements at an urban (Beijing) and a rural site (Gucheng) in summer and winter in the North China
\end{abstract}

Plain, we estimated that the average mass concentrations of $\mathrm{NO}_{3, \text { org }}\left(1.8 \mu \mathrm{g} \mathrm{m}^{-3}\right.$ vs. $\left.1.0 \mu \mathrm{g} \mathrm{m}^{-3}\right)$ and pON to OA $(27.5 \%$ vs. $14.8 \%$ ) were higher in summer than in winter in Beijing, indicating more pON formation in biogenically and anthropogenically mixed environments. In addition, the aver-

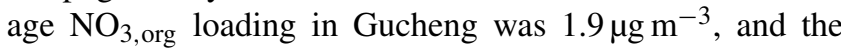
$\mathrm{pON}$ at the rural site also showed higher contribution to OA than that in Beijing during wintertime due to higher primary emissions and gaseous precursors in Gucheng. In addition, $R_{\mathrm{ON}}$ was determined and showed considerable differences between day-night and clean-polluted periods, highlighting the complexity of pON compounds from different chemical pathways (e.g., $\mathrm{OH}$ and $\mathrm{NO}_{3}$ oxidation) and sources. 


\section{Introduction}

Particulate organic nitrates (pON), accounting for 5\%-77\% of organic aerosol (OA) (Ng et al., 2017), are important atmospheric constituents as they affect $\mathrm{NO}_{x}$ recycling, ozone and secondary organic aerosol (SOA) production (Perring et al., 2013; Romer Present et al., 2020). Most previous studies on pON quantification are based on filter measurements using gas chromatography (GC) (O'Brien et al., 1995) and Fourier transformed infrared (FTIR) spectroscopy (Blando et al., 1998). Online measurement techniques - e.g., thermal dissociation-laser-induced fluorescence (TD-LIF) (Day et al., 2002), thermal dissociation-cavity ring-down spectroscopy (TD-CRDS) (Thieser et al., 2016) and thermal dissociation-cavity attenuated phase shift spectroscopy (TDCAPS) (Sadanaga et al., 2016) - were also used to characterize pON in the atmosphere. The principle is to convert pON to $\mathrm{NO}_{2}$ first and then to subtract ambient $\mathrm{NO}_{2}$ from the total $\mathrm{NO}_{2}$. However, the pON may not be accurately quantified under ambient- $\mathrm{NO}_{2}$-dominated conditions. A highresolution time-of-flight chemical ionization mass spectrometer (HR-ToF-CIMS) using iodide-adduct ionization (Lee et al., 2014) with a filter inlet for gases and aerosols (FIGAERO) (Lopez-Hilfiker et al., 2014) (FIGAERO-CIMS) allows for simultaneous characterization of molecular compositions of gas and particle phases of ON. However, the lack of authentic ON standards and different instrument sensitivity for various ON compounds increase the challenges in quantification of pON.

Recently, pON were also quantified using a highresolution aerosol mass spectrometer (HR-AMS) mainly based on the differences of fragmentation patterns between pON and inorganic nitrate (Xu et al., 2015b; Farmer et al., 2010; Kortelainen et al., 2017; Ng et al., 2017). The "PMF method" and "NO${ }_{x}$ method" are the two most commonly used methods for pON quantification (Fry et al., 2013; Xu et al., 2015b; Yu et al., 2019; Dai et al., 2019). The PMF method, which combines organic and inorganic fragments in positive matrix factorization (PMF) analysis, was able to identify organic aerosol factors that showed a largely different $\mathrm{NO}^{+} / \mathrm{NO}_{2}^{+}$ratio from pure ammonium nitrate (AN). The $\mathrm{NO}_{x}$ fragments are then assumed to be mainly from pON (Xu et al., 2015b; Zhang et al., 2016). However, the separation of inorganic and organic $\mathrm{NO}_{x}^{+}$may be limited by the bilinear model depending on the correlations between inorganic nitrate and $\mathrm{pON}$. In addition, some primary organic aerosol (POA) factors from the PMF method also contained much higher $\mathrm{NO}^{+}$or $\mathrm{NO}_{2}^{+}$compared to directly measured mass spectrum of primary emissions (Xu et al., 2020) (Fig. S1 in the Supplement), increasing the uncertainties in quantification of pON. The $\mathrm{NO}_{x}$ method is based on the upper and lower bounds of $R_{\mathrm{ON}}$ (ratio of $\mathrm{NO}^{+}$to $\mathrm{NO}_{2}^{+}$ of $\mathrm{pON})$, which were determined from oxidations of isoprene and monoterpenes ( $\beta$-pinene) with nitrate $\left(\mathrm{NO}_{3}\right)$ radicals (Fry et al., 2009; Bruns et al., 2010; Boyd et al., 2015).
One of the major uncertainties is that $R_{\mathrm{ON}}$ varies largely depending on reaction conditions and precursors in ambient air rather than being constant values. Nevertheless, previous field studies failed to explore the temporal variation of $R_{\mathrm{ON}}$ due to the limitation of methods and the diversity of pON. In some environments, the measured ratio of $\mathrm{NO}^{+}$to $\mathrm{NO}_{2}^{+}$in ambient air is even lower than the average ratio of $\mathrm{NO}^{+}$to $\mathrm{NO}_{2}^{+}$from ammonium nitrate $\left(R_{\mathrm{AN}}\right)$, resulting in negative values of pON estimated by the $\mathrm{NO}_{x}$ method, especially for the wintertime in China, when aerosol particles are dominated by inorganic nitrate (Yu et al., 2019; Zhu et al., 2016). Despite the uncertainties above, extensive studies have been conducted to characterize spatial and seasonal variations of $\mathrm{pON}$ in low- $\mathrm{NO}_{x}$ environments with high biogenic emissions, e.g., the southeastern United States and Europe (Kiendler-Scharr et al., 2016; Lee et al., 2016; Xu et al., 2015b; Ng et al., 2017). Similar work, however, is limited in China, especially in northern China, with high emissions of $\mathrm{NO}_{x}$ and anthropogenic volatile organic compounds (VOCs). In recent years, some studies have explored the concentrations of pON at two background sites in spring (Zhu et al., 2016) and during biomass burning and coal combustion periods in Beijing (Zhang et al., 2016). Yu et al. (2019) found a good correlation between $\mathrm{pON}$ and fresh SOA at night at an urban site in southern China based on the $\mathrm{NO}_{x}$ method and the PMF method. In contrast, Qiao et al. (2021) reported that pON were more correlated with the emission from biomass burning but poorly correlated with less-oxidized oxygenated OA (LO-OOA) at a rural site (Xianghe) in summer. Despite these results, our understanding of the levels, sources and processes of pON in the North China Plain (NCP) remains poor.

In this study, we demonstrate the applications of thermodenuder (TD)-HR-AMS in characterization of pON (referred to as the "TD-AMS method") during wintertime and summertime in NCP (including an urban site and a rural site) and compare pON mass loadings from three different methods, i.e., the $\mathrm{NO}_{x}$ method, PMF method and TD-AMS method. The temporal variation of $R_{\mathrm{ON}}$ during three campaigns is elucidated. The mass loadings and diurnal variations of $\mathrm{pON}$ during one summer and two winter campaigns are elucidated, and the impacts of relative humidity $(\mathrm{RH})$ and temperature on pON are discussed.

\section{Experimental methods}

\subsection{Experimental setup}

This study was performed at the Institute of Atmospheric Physics, an urban site in Beijing, and Gucheng, a rural site in Hebei province. The field observations at the urban site were conducted in summer from 20 May to 23 June and winter from 20 November to 25 December in 2018, and at the rural site from 10 December 2019 to 13 January 2020. All 
data in this study are reported in Beijing local time. The setup and operations of TD and HR-AMS were similar to previous studies (Xu et al., 2019). The HR-AMS that was operated in $\mathrm{V}$ mode with a time resolution of $3 \mathrm{~min}$ was placed downstream of the TD. TD alternated between the bypass line and TD line in a cycle of $30 \mathrm{~min}$. The TD heating temperature was set as $50,70,90,109,120,127$ and $250^{\circ} \mathrm{C}$ in summer and $50,70,90,109,127,150$ and $250^{\circ} \mathrm{C}$ in winter in Beijing, while in winter of 2019 in Gucheng the setting TD temperature ramped linearly from 50 to $250{ }^{\circ} \mathrm{C}$ with a sampling cycle of $150 \mathrm{~min}$. The average particle loss in the TD was corrected according to the calibration by using $\mathrm{NaCl}$ and was found to be $10 \%$ (Huffman et al., 2008).

\subsection{Data analysis}

The HR-AMS data analysis was performed using PIKA (V 1.62F). The HR-AMS was calibrated for ionization efficiency (IE) using pure ammonium nitrate by following the standard protocols (Jayne et al., 2000). Here, we apply three independent methods of quantifying pON. Note that the default relative ionization efficiencies (RIEs) of 1.1 and 1.4 were applied for inorganic nitrate and $\mathrm{NO}_{3}$,org, respectively, during three campaigns. Considering the high mass fraction of ammonium nitrate, the composition-dependent collection efficiency (CDCE) was applied to the bypass data (Middlebrook et al., 2012). In contrast, a constant $\mathrm{CE}$ of 0.5 was used for those from TD, consistent with the data processing in previous studies ( $\mathrm{Xu}$ et al., 2016; Huffman et al., 2009). The elemental composition of OA was calculated using the "improved-ambient (I-A)" method (Canagaratna et al., 2015).

The first method is the $\mathrm{NO}_{x}$ method, which is based on the differences in the $\mathrm{NO}^{+} / \mathrm{NO}_{2}^{+}$ratio between organic and inorganic nitrates (Farmer et al., 2010; Xu et al., 2015b). The $R_{\mathrm{AN}}$ was determined from IE calibrations as 3.7 in summer and 3.4 in winter in both Beijing and Gucheng. However, we found that the winter $R_{\mathrm{AN}}$ was higher than those from ambient observations. Therefore, we chose a period with high $\mathrm{NO}_{3}$ loadings (assuming predominant inorganic nitrate $\left(\mathrm{NO}_{3}\right.$,inorg $)$ contribution) to determine $R_{\mathrm{AN}}$, which was 2.8 and 2.2 , respectively, in Beijing and Gucheng in winter. Note that $\mathrm{NO}_{3}$, org loadings calculated by the $\mathrm{NO}_{x}$ method were slightly underestimated in winter in this case due to the organic nitrate contribution even in a period with high $\mathrm{NO}_{3}$ loadings. In addition, the large uncertainties in pON quantification were found from the $\mathrm{NO}_{x}$ method at high PM levels during wintertime due to the assumption for $R_{\mathrm{AN}}$. To reduce the effect of variation in $R_{\mathrm{ON}}$ values among different instruments, we determined $R_{\mathrm{ON}}$ by multiplying $R_{\mathrm{ON}} / R_{\mathrm{AN}}$ with $R_{\mathrm{AN}}$ in using the $\mathrm{NO}_{x}$ method, assuming that $R_{\mathrm{ON}} / R_{\mathrm{AN}}$ is independent of the instrument (Fry et al., 2013). The $R_{\mathrm{ON}} / R_{\mathrm{AN}}$ ratios of 2.08 and 4.17 from isoprene and $\beta$-pinene oxidation experiments were used as upper and lower bounds of pON in this study (Xu et al., 2015b). Hence,
$R_{\mathrm{ON}}$ of 7 and 15, 5 and 12, and 4 and 10 obtained in summer and winter in Beijing and Gucheng during wintertime, respectively, were used to estimate the upper and lower bounds of pON loadings in this study.

The second method is PMF analysis of combined organic and inorganic aerosol (referred to as the PMF method) (Sun et al., 2012; Yu et al., 2019; Xu et al., 2015b). By including $\mathrm{NO}^{+}$and $\mathrm{NO}_{2}^{+}$ions, PMF analysis was able to separate organic from inorganic nitrates. For instance, Sun et al. (2012) performed factor analysis on combined organic and inorganic aerosol mass spectra and found that the $\mathrm{NO}^{+}$ and $\mathrm{NO}_{2}^{+}$ions in the nitrate factor were dominantly from inorganics and that the ratio of $\mathrm{NO}^{+} / \mathrm{NO}_{2}^{+}$was close to that of pure ammonium nitrate, while those in OA factors with high $\mathrm{NO}^{+} / \mathrm{NO}_{2}^{+}$were generally assumed as organic nitrates in summer in New York City. In this study, the concentrations of $\mathrm{NO}_{3}$, org are calculated by summing up $\mathrm{NO}^{+}$and $\mathrm{NO}_{2}^{+}$from both POA and SOA factors. The time series and mass spectra of PMF factors resolved from $\mathrm{PMF}_{\mathrm{Org}}$ and $\mathrm{PMF}_{\mathrm{Org}}+\mathrm{NO}_{3}$ are shown in Figs. S2-S3. The mass spectral profiles of all PMF factors resolved from $\mathrm{PMF}_{\mathrm{Org}+\mathrm{NO}_{3}}$ are similar to those previously resolved in ambient air (Yu et al., 2019; Xu et al., 2015b). The mass concentrations of PMF factors resolved from $\mathrm{PMF}_{\mathrm{Org}+\mathrm{NO}_{3}}$ overall were well correlated with that from $\mathrm{PMF}_{\mathrm{Org}}$ (Table S2) and also resembled their related tracers. However, some discrepancies in mass concentrations were observed. For example, the concentrations of MO-OOA and $\mathrm{LO}-\mathrm{OOA}$ resolved from $\mathrm{PMF}_{\mathrm{Org}}$ were lower than that from $\mathrm{PMF}_{\mathrm{Org}+\mathrm{NO}_{3}}$, which was caused by the signals of $\mathrm{NO}_{x}^{+}$ in mass spectra of SOA in winter in Beijing. The OA factors representing different sources were identified by PMF, and detailed PMF analyses from the three campaigns have been given in $\mathrm{Xu}$ et al. (2021) and Chen et al. (2021).

The third method denotes the TD-AMS method, which is based on the different volatility between organic and inorganic nitrates. Briefly, $\mathrm{NO}^{+}$and $\mathrm{NO}_{2}^{+}$(hereafter $\mathrm{NO}_{x}^{+}$) signals in HR-AMS mass spectra can be from fragmentation of both particulate organic and inorganic nitrates, whereas $\mathrm{C}_{x} \mathrm{H}_{y} \mathrm{~N}_{z}^{+}$and $\mathrm{C}_{x} \mathrm{H}_{y} \mathrm{O}_{z} \mathrm{~N}_{p}^{+}$are completely from particulate organic nitrogen compounds including $\mathrm{ON}$ and other nitrogen-containing organic compounds. The $\mathrm{C}_{x} \mathrm{H}_{y} \mathrm{~N}_{z}^{+}$and $\mathrm{C}_{x} \mathrm{H}_{y} \mathrm{O}_{z} \mathrm{~N}_{p}^{+}$dominated the $\mathrm{N}$ mass for non-ON organic nitrogen compounds (Fig. S4), while $\mathrm{NO}^{+}$and $\mathrm{NO}_{2}^{+}$were the main N-containing ions for ON (Farmer et al., 2010; Boyd et al., 2015; $\mathrm{Xu}$ et al., 2015a). Note that the $\mathrm{C}_{x} \mathrm{H}_{y} \mathrm{~N}_{z}^{+}$and $\mathrm{C}_{x} \mathrm{H}_{y} \mathrm{O}_{z} \mathrm{~N}_{p}^{+}$families refer to the sum of $\mathrm{N}$-containing ions at $m / z<60$ due to the limited mass resolution of $\mathrm{V}$ mode (Xu et al., 2017b). Owing to the higher volatility of $\mathrm{NO}_{3}$,inorg than ON (Huffman et al., 2008; Ng et al., 2017), the remaining mass loadings of nitrate fragments from pON (denoted as $\mathrm{NO}_{x, \text { org }}^{+}$) are expected to be much higher than that of nitrate fragments from inorganic nitrates (denoted as $\mathrm{NO}_{x, \text { inorg }}^{+}$) at high TD temperatures (Huffman et al., 2008; Berkemeier et al., 2020). As shown in Fig. $1, \mathrm{NO}^{+}$and $\mathrm{NO}_{2}^{+}$decreased sig- 

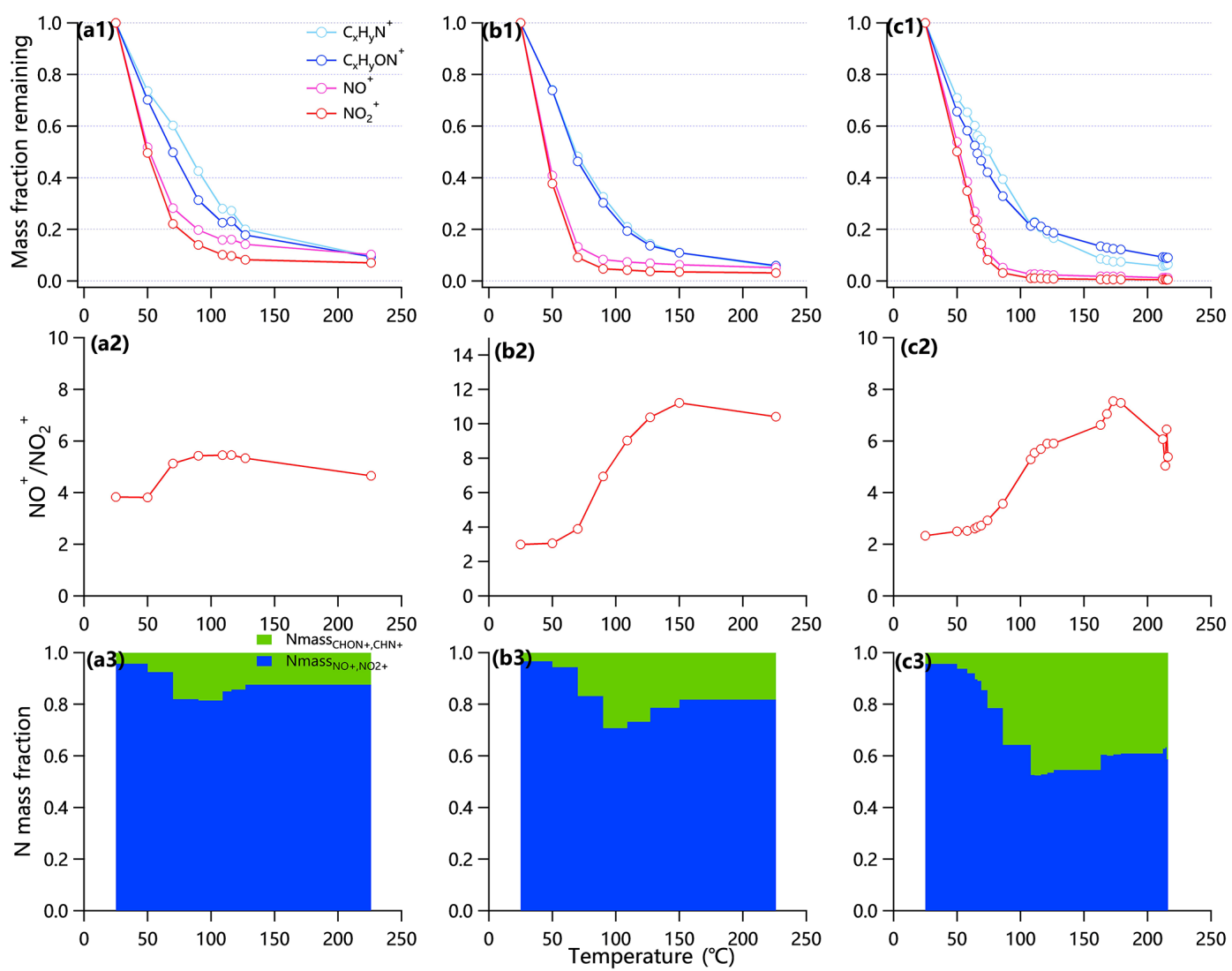

Figure 1. Thermograms of $\mathrm{C}_{x} \mathrm{H}_{y} \mathrm{~N}^{+}, \mathrm{C}_{x} \mathrm{H}_{y} \mathrm{ON}^{+}, \mathrm{NO}^{+}$and $\mathrm{NO}_{2}^{+}$in (a) summer in Beijing, (b) winter in Beijing and (c) winter in Gucheng. Variations of the fraction of $\mathrm{N}$ mass from $\mathrm{N}$-containing ions and the ratio of $\mathrm{NO}^{+}$to $\mathrm{NO}_{2}^{+}$as a function of temperature are also shown.

nificantly from 25 to $90^{\circ} \mathrm{C}$, whereas the decreases slowed down substantially for $T>90^{\circ} \mathrm{C}$. Hence, we assumed that the $\mathrm{NO}_{3 \text {,inorg }}$ evaporated completely at $T=90^{\circ} \mathrm{C}$. In addition, the $\mathrm{N}$ mass from $\mathrm{NO}^{+}$and $\mathrm{NO}_{2}^{+}$dominated the total $\mathrm{N}$ at $T>90^{\circ} \mathrm{C}$ (Fig. 1a3-c3), indicating that pON dominated the total particulate organic nitrogen compounds in NCP in both summer and winter. The $\mathrm{NO}_{x}^{+}$measured by HR-AMS for $T>90^{\circ} \mathrm{C}$ was the remaining organic nitrate compounds upon heating, consistent with previous studies reporting a complete evaporation of pure $\mathrm{AN}$ at $\sim 60^{\circ} \mathrm{C}$ (Huffman et al., 2008). The slightly different evaporation temperature of AN between this study and Huffman et al. (2008) could be due to the different aerosol mixing states in different environments. For example, Li et al. (2021) and Liu et al. (2021) found that secondary inorganic aerosol (SIA) particles were frequently coated with organics in NCP, which may affect the evaporation temperature of AN.

Assuming that the volatility of pON can be represented by total organic nitrogen compounds, the mass concentrations of pON in ambient air can be determined as

$\left[\mathrm{NO}_{3, \text { org }}\right]=\frac{\left[\mathrm{NO}_{3}\right]_{T=90^{\circ} \mathrm{C}}}{\mathrm{MFR}_{\mathrm{CHN}^{+}+\mathrm{CHON}^{+} T=90^{\circ} \mathrm{C}}}$.
The ratio of $\mathrm{NO}^{+}$to $\mathrm{NO}_{2}^{+}$of $\mathrm{pON}$ (denoted as $R_{\mathrm{ON} \text {,calc }}$ ) can be determined as

$$
\begin{aligned}
& {\left[\mathrm{NO}_{3, \text { inorg }}\right]=\left[\mathrm{NO}_{3}\right]-\left[\mathrm{NO}_{3, \text { org }}\right],} \\
& {\left[\mathrm{NO}_{\text {inorg }}\right]=\frac{R_{\mathrm{AN}}}{1+R_{\mathrm{AN}}} \times\left[\mathrm{NO}_{3, \text { inorg }}\right],} \\
& {\left[\mathrm{NO}_{2, \text { inorg }}\right]=\frac{1}{1+R_{\mathrm{AN}}} \times\left[\mathrm{NO}_{3, \text { inorg }}\right],} \\
& {\left[\mathrm{NO}_{\text {org }}\right]=[\mathrm{NO}]-\left[\mathrm{NO}_{\text {inorg }}\right],} \\
& {\left[\mathrm{NO}_{2, \text { org }}\right]=\left[\mathrm{NO}_{2}\right]-\left[\mathrm{NO}_{2, \text { inorg }}\right],} \\
& R_{\mathrm{ON}, \text { calc }}=\frac{\left[\mathrm{NO}_{\text {org }}\right]}{\left[\mathrm{NO}_{2, \text { org }}\right]} .
\end{aligned}
$$

The subscript " $T=90^{\circ} \mathrm{C}$ " denotes the mass concentrations and mass fraction remaining (MFR) of fragments at $T=$ $90^{\circ} \mathrm{C}$. The subscripts "org" and "inorg" denote the mass concentration of fragments of particulate organic and inorganic nitrates. $\mathrm{NO}, \mathrm{NO}_{2}$ and $\mathrm{NO}_{3}$ are the measured mass concentrations of total nitrate fragments. $R_{\mathrm{AN}}$ is the average ratio of $\mathrm{NO}^{+}$to $\mathrm{NO}_{2}^{+}$from ammonium nitrate. The sensitive tests of $\mathrm{NO}_{3, \text { org }}$ and $R_{\mathrm{ON}}$ with the variation of MFR and $R_{\mathrm{AN}}$ are 
shown in Fig. S5, demonstrating the impact of accurate determination of MFR and $R_{\mathrm{AN}}$ on $R_{\mathrm{ON}}$ in the TD-AMS method.

Note that the pON / OA ratio in this study refers to the contribution of pON to total OA including the contribution of nitrate functional groups (i.e., total $\mathrm{OA}=\mathrm{Org}+\mathrm{NO}_{3}$, org ). The conversion method from $\mathrm{NO}_{3}$,org / Org into pON / OA is illustrated in Takeuchi and $\mathrm{Ng}$ (2019).

\section{Results and discussion}

\subsection{Intercomparisons}

Figure 2 shows the $\mathrm{NO}_{3}$, org mass loadings estimated using three different methods during three campaigns. The

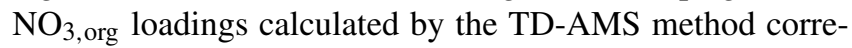
lated well with those of the $\mathrm{NO}_{x}$ method during summertime $\left(R^{2}=0.62\right)$, but different slopes were found in different periods of the measurements. For example, the slope was 1.1 during $15-17$ June $\left(R^{2}=0.94\right)$, implying higher $\mathrm{NO}_{3 \text {, org }}$ loadings calculated by the $\mathrm{NO}_{x}$ method with $R_{\mathrm{ON}}=15$ than that using the TD-AMS method. Comparatively, the slope was 0.35 during $11-12$ June $\left(R^{2}=0.62\right)$, suggesting lower loadings from the $\mathrm{NO}_{x}$ method. Such differences were likely due to different pON species that were formed under different precursors and meteorological conditions (e.g., temperature, $\mathrm{NO}_{x}$ levels and $\mathrm{RH}$ ). Also, the slope differences indicate the variations of $\mathrm{pON}$ compounds leading to the variation of $R_{\mathrm{ON}}\left(R_{\mathrm{ON} \text {, calc }}=5.0\right.$ during 11-12 June vs. 13.6 during 15-17 June), highlighting the importance of determining the time-dependent $R_{\mathrm{ON}}$. On average, the mass concentration of $\mathrm{NO}_{3}$, org calculated by the TD-AMS method in summer was $1.8 \mu \mathrm{g} \mathrm{m}^{-3}$, which was slightly higher than that from the $\mathrm{NO}_{x}$ method $\left(1.0-1.5 \mu \mathrm{g} \mathrm{m}^{-3}\right)$. Negative $\mathrm{NO}_{3 \text {, org }}$ mass loadings from the $\mathrm{NO}_{x}$ method were observed, accounting for $8.5 \%$ and $12.8 \%$ of the time during wintertime in Beijing and Gucheng, respectively. This phenomenon has also been observed in previous studies in China (Zhu et al., 2016; Yu et al., 2019), particularly in winter, and was likely due to (1) high emissions of anthropogenic volatile organic compounds (AVOCs) and high- $\mathrm{NO}_{x}$ conditions resulting in similar $R_{\mathrm{ON}}$ and $R_{\mathrm{AN}}$ and (2) much higher inorganic nitrate loading than pON. As shown in Fig. 2, the $\mathrm{NO}_{3}$, org from the TD-AMS method correlated well with that from the $\mathrm{NO}_{x}$ method, yet the mass loadings deviated from the lower and upper bounds from the $\mathrm{NO}_{x}$ method during some periods, likely due to different pON compounds. The $\mathrm{NO}_{3}$, org loadings from the $\mathrm{NO}_{x}$ method ranged from 0.9 to $1.3 \mu \mathrm{g} \mathrm{m}^{-3}$ and from 0.8 to $1.6 \mu \mathrm{g} \mathrm{m}^{-3}$ in Beijing and Gucheng during wintertime, respectively, which is overall comparable to that of the TD-AMS method in Beijing $\left(1.0 \mu \mathrm{g} \mathrm{m}^{-3}\right)$ and slightly lower than that in Gucheng $\left(1.9 \mu \mathrm{g} \mathrm{m}^{-3}\right)$.

The average mass concentration of $\mathrm{NO}_{3}$,org calculated from the PMF method $\left(0.28 \mu \mathrm{g} \mathrm{m}^{-3}\right)$ is much lower than those from the other two methods in summer in Beijing, in agreement with the results in the southeastern USA $(\mathrm{Xu}$ et al., 2015b). In contrast, the average $\mathrm{NO}_{3 \text {, org }}\left(2.5 \mu \mathrm{g} \mathrm{m}^{-3}\right)$ in winter in Beijing was higher, and that $\left(1.8 \mu \mathrm{g} \mathrm{m}^{-3}\right)$ in winter in Gucheng was comparable to that from the other two methods. Such differences during three campaigns indicate that the uncertainties of the PMF method in estimation of $\mathrm{NO}_{3, \text { org }}$ can originate from, for example, (1) the incorrect assignment of $\mathrm{NO}^{+}$and $\mathrm{NO}_{2}^{+}$to POA factors, (2) the different ratio of $\mathrm{NO}^{+}$to $\mathrm{NO}_{2}^{+}$in the nitrate inorganic aerosol (NIA) factor from pure ammonium nitrate, and (3) the contribution of organic ions to the NIA factor. As shown in Fig. S2, the nitrogen-containing fragments $\left(\mathrm{C}_{x} \mathrm{H}_{y} \mathrm{~N}^{+}\right.$, accounting for $5 \%$ of NIA) were unexpectedly assigned to the NIA factor, while the $\mathrm{NO}_{x}^{+}$in MO-OOA, a factor often related to aqueous-phase processing ( $\mathrm{Xu}$ et al., 2017a), were negligible, resulting in the minor response of $\mathrm{NO}_{3}$, org loadings as a function of RH. This is also supported by the fact that the concentrations of $\mathrm{NO}_{3}$, org from the PMF method were much lower than those from the TD-AMS method at high RH levels $(10-12$ June, $\mathrm{RH}=70 \%)$. The $\mathrm{NO}_{x}^{+}$signals assigned to POA in winter in Beijing were much higher than those in source emission experiments. For example, $f_{\mathrm{NO}^{+}}$ $(3.5 \%)$ and $f_{\mathrm{NO}_{2}^{+}}\left(1.5 \%\right.$, fractions of $\mathrm{NO}^{+}$or $\mathrm{NO}_{2}^{+}$in total mass spectrum) of biomass burning OA (BBOA) in winter in Beijing (Fig. S3) were higher than those from burning of different biofuels $\left(f_{\mathrm{NO}^{+}}=0.9 \%\right.$ and $\left.f_{\mathrm{NO}_{2}^{+}}=0.65 \%\right)(\mathrm{Xu}$ et al., 2020). Further analysis suggested that the episodes dominated by POA also resulted in higher pON loadings from the PMF method in winter in Beijing. Considering the uncertainties of the PMF method, the following discussions are mainly based on the results from the TD-AMS method and $\mathrm{NO}_{x}$ method.

The average mass concentration of $\mathrm{NO}_{3, \text { org }}$ in summer was higher than that in winter in Beijing, consistent with the contribution of $\mathrm{NO}_{3}$, org to $\mathrm{NO}_{3}(24.1 \%$ vs. $9.8 \%)$. This result is consistent with the seasonal variation of $\mathrm{NO}_{3}$, org loadings observed in the southeastern USA (Xu et al., 2015b). One explanation is stronger secondary formation during summertime than winter, as indicated by the higher fraction of SOA and SIA (Zhou et al., 2020). The dominant biogenic volatile organic compounds (BVOCs) in summer and AVOCs in winter (Liu et al., 2020) would be another reason for the differences in pON loadings in two seasons. The contribution of $\mathrm{NO}_{3, \text { org }}$ to $\mathrm{NO}_{3}(9.8 \%$ vs. $11.6 \%)$ was comparable between Beijing and Gucheng during wintertime, yet the average $\mathrm{NO}_{3}$, org in Gucheng was higher than that in Beijing during wintertime. This can be attributed to much higher anthropogenic emissions (e.g., coal combustion and biomass burning) at the rural site than urban site (Sun et al., 2020; Xu et al., 2021), resulting in different pON compounds as suggested by the different $R_{\mathrm{ON}}\left(R_{\mathrm{ON} \text {,calc }}=2.2\right.$ in Beijing and 4.3 in Gucheng on average). Also, the variations of $\mathrm{N}$ mass contributions from different $\mathrm{N}$-containing ions as a function of TD temperature supported the differences in pON com- 

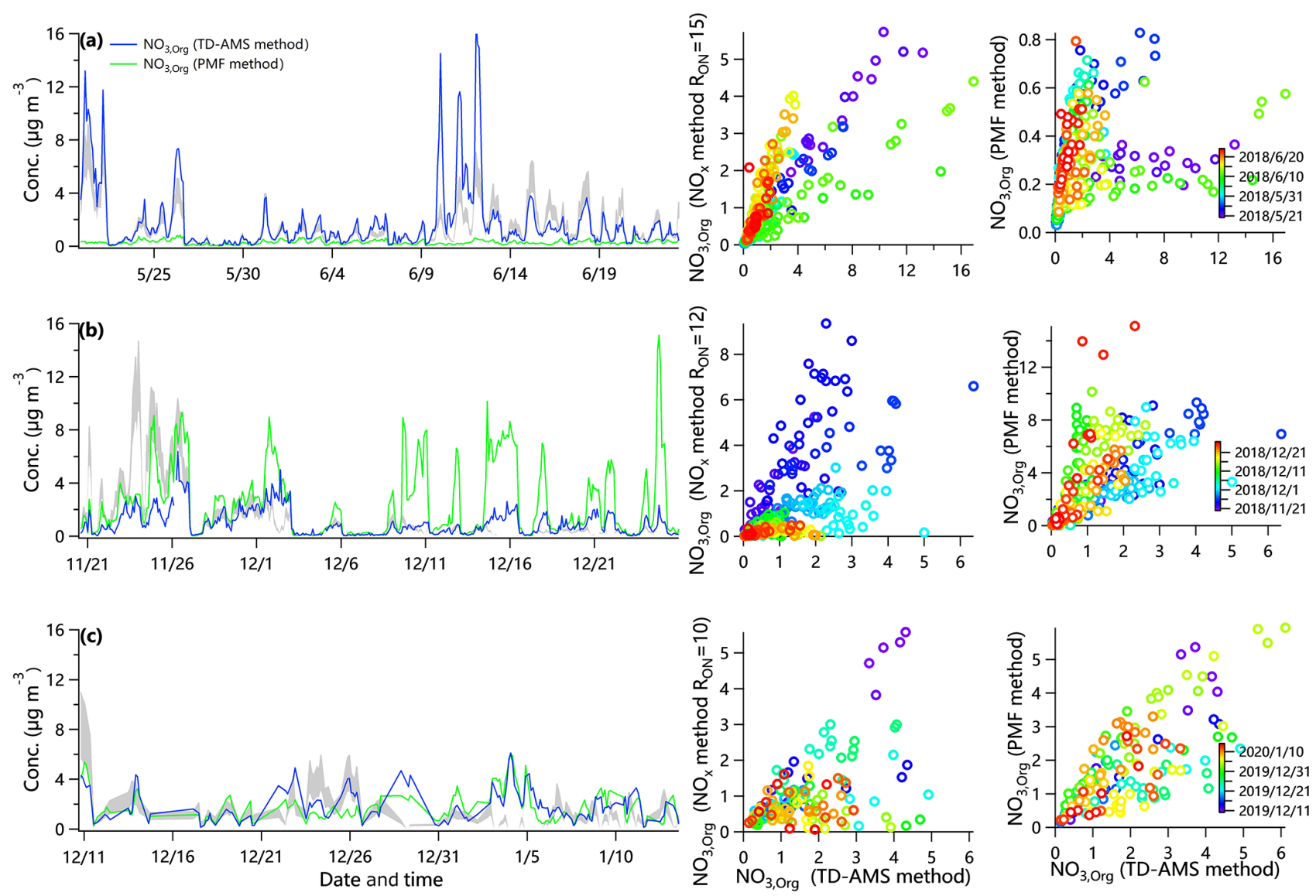

Figure 2. Intercomparisons of $\mathrm{NO}_{3}$, org mass loadings using three different methods in (a) summer in Beijing, (b) winter in Beijing and (c) Gucheng. The top and bottom of shaded areas in time series are the upper and lower bounds of pON loadings from the "NO $x$ method".

pounds (Fig. 1). Note that the contribution of pON (assuming $\left.\mathrm{MW}_{\mathrm{ON}}=200 \mathrm{~g} \mathrm{~mol}^{-1}\right)$ to OA in NCP $(14.8 \%-27.5 \%)$ was in the range of previous studies ( $\mathrm{Ng}$ et al., 2017; Yu et al., 2019), and the seasonal variations of pON / OA in Beijing ( $14.8 \%$ in winter vs. $27.5 \%$ in summer, Table S1) were also similar to previous studies (Xu et al., 2015b). The higher contribution of pON to OA in Gucheng than Beijing (24.0\% vs. $14.8 \%$ ) indicated a more important role of $\mathrm{pON}$ in $\mathrm{OA}$ at the rural site in NCP during wintertime.

The negligible correlation of $\mathrm{NO}_{3}$, org with POA in summer in Beijing $\left(R^{2}=0.05\right)$ is in contradiction with the results in Xianghe (a rural site in NCP), which shows that pON formation might be highly associated with primary emissions (Qiao et al., 2021). Such differences were caused by the different primary emission in different environments. For example, BBOA is the dominant POA in Xianghe (Qiao et al., 2021) but not in Beijing during summertime. The higher correlation of $\mathrm{NO}_{3}$, org with POA was found in winter in NCP $\left(R^{2}=0.49-0.52\right)$, suggesting that primary emissions can be an important source of pON in winter in NCP, which may be related to $\mathrm{NO}_{3}$ oxidation of AVOCs emitted from anthropogenic activities (Li et al., 2019; Lee et al., 2019). Our re- sults are consistent with the considerable contributions of alkanes (a typical AVOC) to pON production in previous field (Lee et al., 2015), model (Jordan et al., 2008) and chamber studies (Lim and Ziemann, 2009). In fact, there is a growing consensus about the importance of AVOCs (e.g., styrene (Yu et al., 2019), toluene (Ramasamy et al., 2019) and longchain aliphatics (Matsunaga and Ziemann, 2010)) in pON formation under high- $\mathrm{NO}_{x}$ conditions (Lee et al., 2015; Li et al., 2019; Lee et al., 2019).

\subsection{Diurnal variation}

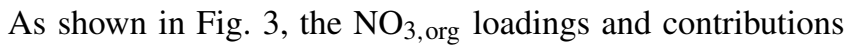
from the TD-AMS method and $\mathrm{NO}_{x}$ method showed similar diurnal profiles in summer in Beijing, which were characterized by decreased concentration during daytime, in agreement with the behaviors of total $\mathrm{NO}_{3}$ in Beijing (Sun et al., 2013) and $\mathrm{NO}_{3, \text { org }}$ in Shenzhen (Yu et al., 2019). The elevated planetary boundary layer and temperature-dependent gas-particle partitioning could be the major reason. We noticed an elevated fraction of $\mathrm{NO}_{3}$,org in $\mathrm{NO}_{3}$ during daytime in summer, likely suggesting that photochemical processing played an important role in the formation of $\mathrm{pON}$ in summer 
in Beijing. This is consistent with the moderate correlation of $\mathrm{O}_{x}$ with $\mathrm{NO}_{3, \text { org }}$ during 12:00-18:00 and tight correlation between LO-OOA, an OA factor related to photochemical production (Xu et al., 2017a), and $\mathrm{NO}_{3, \text { org }}$ from 06:00-16:00 during summertime (Fig. S6). Note that $\mathrm{NO}_{3}$, org loadings, the contributions of pON to OA and $\mathrm{NO}_{3, \text { org }} / \mathrm{NO}_{3}$ showed apparent increases starting at 20:00 in summer, highlighting the important role of the $\mathrm{NO}_{3}$ radical in the nocturnal pON formation (Fry et al., 2013; Zhang et al., 2016; Ng et al., 2017). Indeed, we calculated the ratio of $\mathrm{NO}^{+}$to $\mathrm{NO}_{2}^{+}$of ON during daytime and nighttime and found higher $R_{\mathrm{ON}}$ at night $\left(R_{\mathrm{ON}, \mathrm{calc}}=5.8 \pm 2.8\right)$ than daytime $\left(R_{\mathrm{ON}, \mathrm{calc}}=5.2 \pm 3.0\right)$ in summer (Fig. S7; the $t$ value of 1.79 between day and night was larger than that at the $90 \%$ confidence level, 1.66), suggesting that the pON compounds from $\mathrm{OH}$-initiated and $\mathrm{NO}_{3}$-initiated chemical reactions were different. This higher $R_{\mathrm{ON}}$ for $\mathrm{pON}$ formed via $\mathrm{NO}_{3}$ oxidation than those via $\mathrm{OH}$ oxidation is consistent with the results of chamber experiments (Takeuchi and $\mathrm{Ng}, 2019$ ).

The diurnal variations of $\mathrm{NO}_{3 \text {,org }}$ loadings in winter in Beijing and Gucheng were characterized by significant increases during daytime, indicating that photochemical production played an important role in pON formation. However, the fraction of pON in OA remained relatively stable throughout the day, suggesting that photochemical processing also produced other SOA besides pON. $\mathrm{NO}_{3 \text {,org }}$ from the two different methods showed some different trends during some periods in winter (Fig. 3). For example, the $\mathrm{NO}_{3 \text {,org }}$ from the $\mathrm{NO}_{x}$ method dropped at 08:00, while that from the TD-AMS method peaked at 08:00 in winter in Beijing. The differences in $\mathrm{NO}_{3}$,org from the two different methods also appeared in the morning in Gucheng, where $\mathrm{NO}_{3 \text {, org loadings }}$ from the TD-AMS method showed an obvious enhancement at $\sim 06: 00$, yet not in the $\mathrm{NO}_{x}$ method. Also, the fraction of pON from the TD-AMS method in OA $(22.8 \%)$ was higher than that from the $\mathrm{NO}_{x}$ method $(5.7 \%-11.0 \%)$. Such differences in the morning during wintertime could be attributed to the differences in organic nitrogen composition with different volatility and also different $R_{\mathrm{ON}}$ between morning and afternoon. In Beijing in winter, the peak of $\mathrm{NO}_{3}$, org from the TD-AMS method was partly caused by the changes in AVOC emissions (e.g., acetone, benzene, C8 aromatics and toluene) (Sheng et al., 2019). In Gucheng in winter, photochemical aqueous-phase processing was one of the reasons for those differences in the morning due to the frequent occurrence of radiation fog that dissipated after sunrise (Kuang et al., 2020). Overall, our results suggest that the use of a fixed $R_{\mathrm{ON}}$ value in the $\mathrm{NO}_{x}$ method was limited in representing diurnal variation characteristics of $\mathrm{pON}$ in winter in NCP.

\subsection{Dependence of pON on NR-PM 1 loading}

As shown in Fig. 4, $\mathrm{NO}_{3 \text {, org }}$ showed an overall increasing trend with the increase of PM in both summer and winter. However, the variations of pON in OA were different be- tween summer and winter. The pON fractions in OA were comparable $(\sim 14 \%)$ between summer and winter in Beijing on clean days (nonrefractory submicron aerosol (NR$\left.\mathrm{PM}_{1}\right)<20 \mu \mathrm{g} \mathrm{m}^{-3}$ ), yet the $R_{\mathrm{ON}}$ in summer $\left(R_{\mathrm{ON}, \text { calc }}=7.0\right)$ was much higher than that in winter $\left(R_{\mathrm{ON} \text {, calc }}=2.8\right)$, emphasizing the seasonal differences in pON composition. Comparatively, the $\mathrm{pON}$ fraction in $\mathrm{OA}$ at the rural site was higher than that in Beijing in winter, and the $R_{\mathrm{ON}}$ was also different $\left(R_{\mathrm{ON}, \text { calc }}=6.0\right.$ in Gucheng vs. $R_{\mathrm{ON}, \text { calc }}=2.8$ in Beijing $)$, highlighting the very different pON compounds between rural and urban sites during clean days. The fraction of pON in OA at high PM levels shows significant differences. For example, the fraction of pON in OA showed a clear increase as a function of PM and reached $\sim 30 \%$ at high PM levels $\left(>50 \mu \mathrm{g} \mathrm{m}^{-3}\right.$ ) in summer in Beijing, indicating the increased contribution of pON to OA during polluted episodes. Comparatively, the contribution of pON to OA remained small under different PM levels in winter in Beijing and Gucheng. By linking the variations of pON with OA factors, we found that LO-OOA (a factor related to the photochemical processing; $\mathrm{Xu}$ et al., 2017a) shows obvious increase in polluted conditions in summer but not in winter in Beijing (Fig. S8), indicating that photochemical processing played an increasing role in polluted conditions during summer yet a limited role in winter in Beijing. In addition, the largely enhanced primary emissions at high PM levels in winter could be another reason for the lower contribution of pON to OA. Different from the variations of pON / OA, the fraction of $\mathrm{NO}_{3 \text {, org }}$ in total $\mathrm{NO}_{3}$ showed overall decreasing trends as a function of PM levels, indicating that the increases of inorganic nitrate were more rapid than $\mathrm{NO}_{3, \text { org }}$. We found that $\mathrm{NO}_{3 \text {,org was }}$ more important than inorganic nitrate during clean days in summer, contributing $\sim 80 \%$, although the contribution decreased rapidly to $20 \%$ in polluted episodes.

Table 1 summarizes the average $R_{\mathrm{ON} \text {, calc }}$ on clean and polluted days during three campaigns. $R_{\mathrm{ON} \text {,calc }}$ showed a lower value on polluted days than that on clean days, indicating the changes of ON compounds at different PM levels. Note that the $R_{\mathrm{ON} \text {,calc }}$ of 1.2 on polluted days in winter in Beijing was lower than the $R_{\mathrm{AN}}$ of 2.8 . Besides the intense primary emission and complicated precursors in winter, the mixture effect from AVOC and BVOC oxidations may have played a part in this low $R_{\mathrm{ON} \text {,calc }}$, which warrants further studies. In addition, the uncertainties of $R_{\mathrm{AN}}$ from a period with high $\mathrm{NO}_{3}$ loadings could be another possible reason.

\subsection{Effects of meteorological conditions}

Figure 5 shows the variations of $\mathrm{NO}_{3}$,org mass loadings as a function of RH and temperature during daytime (08:0020:00) and nighttime (20:00-08:00) during three campaigns. In general, $\mathrm{NO}_{3, \text { org }}$ showed an increasing trend as a function of RH below $80 \%$ in both daytime and nighttime. Previous studies in NCP showed ubiquitously increased PM levels as a function of RH. In addition to the increased aqueous- 

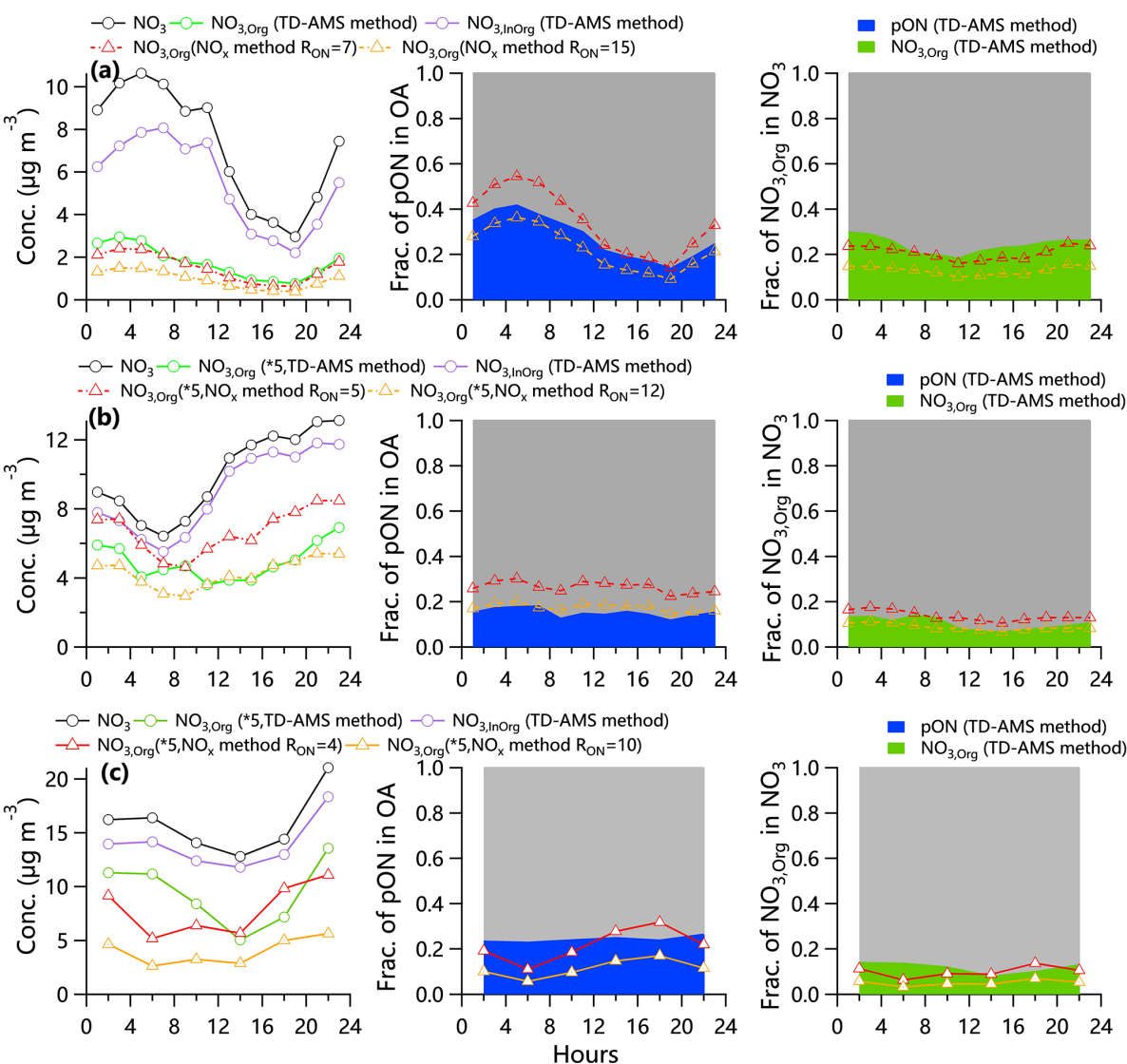

Figure 3. Diurnal profiles of $\mathrm{NO}_{3}$, org loadings, fraction of pON in OA, and fraction of $\mathrm{NO}_{3}$, org in $\mathrm{NO}_{3}$ calculated by the "TD-AMS method" and "NO${ }_{x}$ method" in (a) summer in Beijing, (b) winter in Beijing and (c) winter in Gucheng. Because there are fewer data in Gucheng due to more TD temperature settings, the diurnal profile shows $4 \mathrm{~h}$ averaged data.

Table 1. A summary of average $R_{\mathrm{ON} \text {,calc }}$ during three campaigns.

\begin{tabular}{lrrr}
\hline & Beijing $_{\text {Summer }}$ & Beijing $_{\text {Winter }}$ & Gucheng $_{\text {Winter }}$ \\
\hline NR-PM $_{1}<20 \mu \mathrm{g} \mathrm{m}^{-3}$ & 7.0 & 2.8 & 6.0 \\
NR-PM $_{1}>50 \mu \mathrm{g} \mathrm{m}^{-3}$ & 3.4 & 1.2 & 3.5 \\
Average & 5.7 & 2.2 & 4.3 \\
\hline
\end{tabular}

phase processing, the stagnant meteorological conditions at high $\mathrm{RH}$ levels were often found to be the major reason. Therefore, the increases of $\mathrm{NO}_{3}$,org as a function of $\mathrm{RH}$ could be mainly associated with the increased PM levels. As RH increased above $90 \%$, we observed some decreases in $\mathrm{NO}_{3, \text { org }}$, possibly indicating the impact of hydrolysis of pON (Takeuchi and Ng, 2019; Rindelaub et al., 2015; Liu et al., 2012). However, since OA concentration also exhibited a decreasing trend above $80 \%-90 \% \mathrm{RH}$ as with $\mathrm{NO}_{3 \text {, org }}$, the decrease in $\mathrm{NO}_{3, \text { org }}$ may have been also affected by partitioning. The day and night differences in $\mathrm{NO}_{3}$,org at low and high RH levels are also shown in Fig. 5. For example, we observed higher $\mathrm{NO}_{3}$,org loadings during daytime than nighttime at $\mathrm{RH}<60 \%$, indicating that photochemical formation of pON was more important than nocturnal production, which is further supported by the elevated fraction of $\mathrm{NO}_{3}$,org in $\mathrm{NO}_{3}$ in

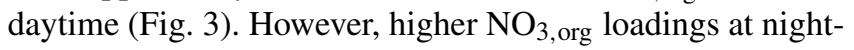
time than daytime were observed at $\mathrm{RH}>60 \%$ in Gucheng, likely suggesting the importance of nocturnal reactions associated with enhanced primary emissions at high RH levels. Overall, the day-night differences highlight the impacts of multiple factors on $\mathrm{ON}$ formation, including precursors (e.g., biogenic and anthropogenic VOCs) and oxidants (e.g., $\mathrm{OH}$ and $\mathrm{NO}_{3}$ radicals), which needs to be further investigated by analyzing molecular compositions of $\mathrm{ON}$.

The $\mathrm{NO}_{3 \text {,org }}$ loadings showed a slightly decreasing trend as a function of $T$ in summer due to the evaporative loss at high temperatures. This result was consistent with the cham- 


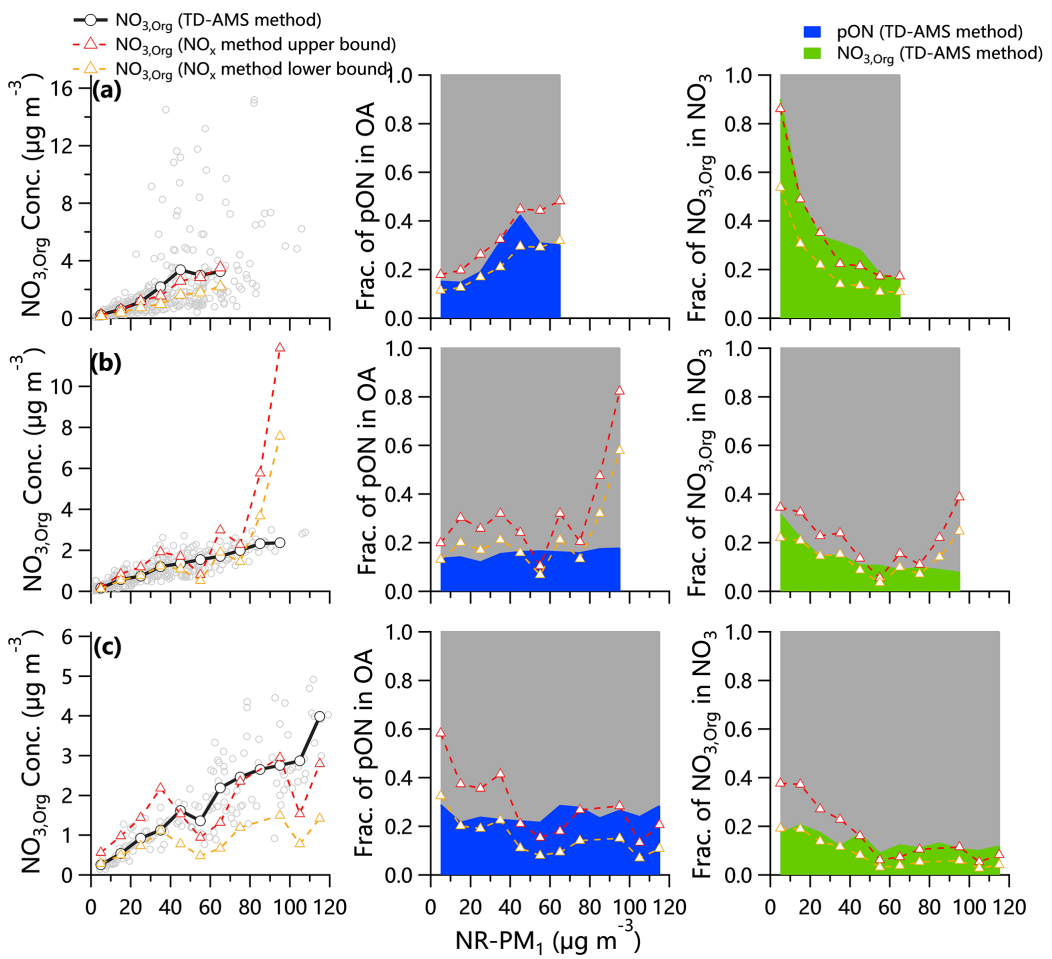

Figure 4. Variations of $\mathrm{NO}_{3}$, org mass loadings, fraction of $\mathrm{pON}$ in $\mathrm{OA}$ and fraction of $\mathrm{NO}_{3}$, org in $\mathrm{NO}_{3}$ as a function of particulate matter (PM) loadings in (a) summer in Beijing, (b) winter in Beijing and (c) winter in Gucheng. Because there are fewer data points in Gucheng due to more TD temperature settings, the chemically resolved PM pollution is $20 \mu \mathrm{g} \mathrm{m}^{-3}$ on average.
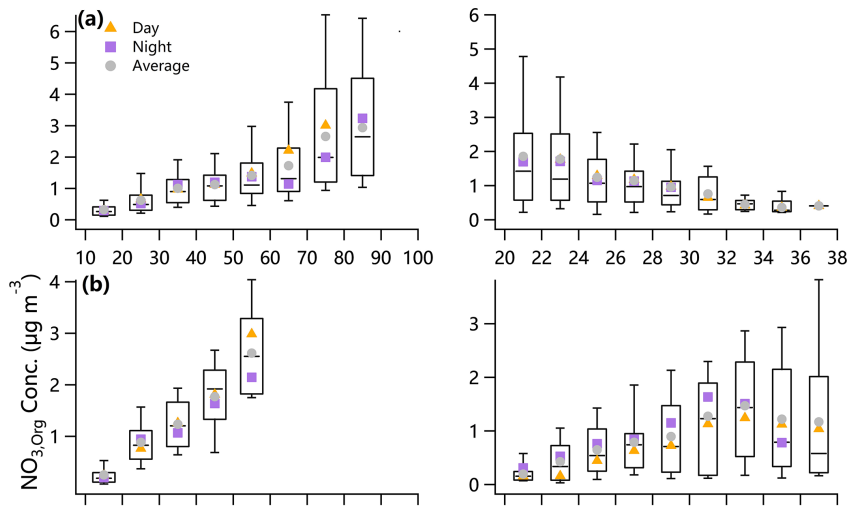

$\begin{array}{llllllllll}10 & 20 & 30 & 40 & 50 & 60 & 70 & 80 & 90 & 100\end{array}$
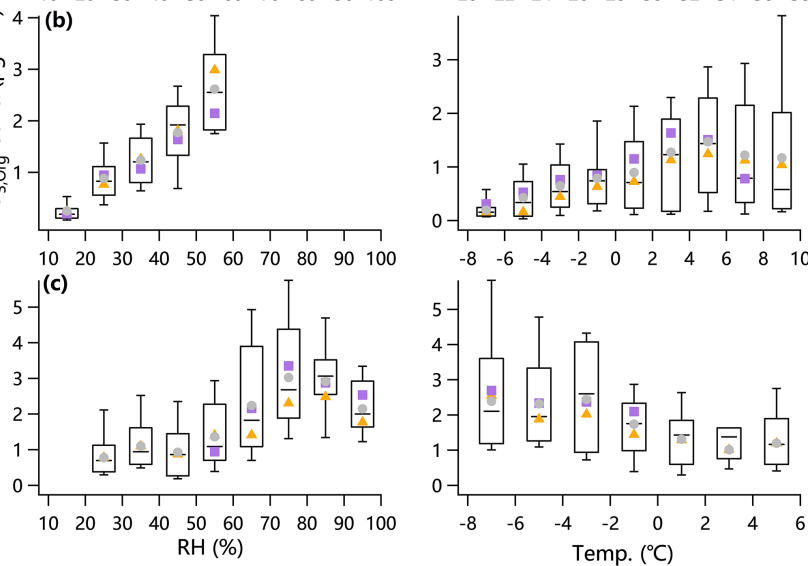

Figure 5. Variations of $\mathrm{NO}_{3}$, org mass loadings as a function of $\mathrm{RH}$ and temperature in (a) summer in Beijing, (b) winter in Beijing and (c) winter in Gucheng calculated by the "TD-AMS method". The mid-point line, lower and upper boxes, and lower and upper whiskers refer to the median, 25th and 75th percentiles, and 10th and 90th percentiles, respectively, for the entire study. ber experiments showing decreasing monoterpenes pON as temperature increased from $\sim 25$ to $\sim 40^{\circ} \mathrm{C}$ (Boyd et al., 2017; Berkemeier et al., 2020). In contrast, the $\mathrm{NO}_{3 \text {,org }}$ loadings in both daytime and nighttime showed increasing trends as a function of $T$ in winter in Beijing, suggesting the importance of photochemical production. In contrast, the $\mathrm{NO}_{3, \text { org }}$ loadings decreased as temperature elevated in Gucheng during wintertime and then remained relatively stable at $T>0{ }^{\circ} \mathrm{C}$. One reason was greatly enhanced primary emissions from residential heating at low temperatures.

\section{Limitations and conclusions}

In this study, we demonstrated the capability of combining HR-AMS and TD measurements to quantify and characterize pON in NCP in summer and winter. However, this approach has several limitations. Firstly, we assumed that $\mathrm{NO}_{3}$,inorg evaporated completely at $T=\sim 90^{\circ} \mathrm{C}$, which might not be the case in some environments and could overestimate evaporative loss of $\mathrm{NO}^{+}$and $\mathrm{NO}_{2}^{+}$from ON. Secondly, the average mass loss of $\mathrm{C}_{x} \mathrm{H}_{y} \mathrm{~N}_{z}^{+}$and $\mathrm{C}_{x} \mathrm{H}_{y} \mathrm{O}_{z} \mathrm{~N}_{p}^{+}$at $T=90^{\circ} \mathrm{C}$ was used as the proportion of mass loss of $\mathrm{pON}$; however, the volatilities of pON vary among different pON species. Indeed, it is challenging to quantify due to the extremely complex pON in ambient air, as well as the absence of pON standards. In addition, separating nitrogen ion fragments is a 
challenge due to the limited resolution of HR-AMS, leading to the uncertainties in calculating mass losses of $\mathrm{C}_{x} \mathrm{H}_{y} \mathrm{~N}_{z}^{+}$ and $\mathrm{C}_{x} \mathrm{H}_{y} \mathrm{O}_{z} \mathrm{~N}_{p}^{+}$. Thirdly, using a default value of RIE 1.4 and a fixed molar mass $\left(\mathrm{MW}_{\mathrm{ON}}=200 \mathrm{~g} \mathrm{~mol}^{-1}\right)$ for estimation of pON would introduce additional uncertainties considering the complexity of pON compounds. Fourthly, the low-volatility nitrogen-containing compounds (e.g., metal nitrates) with a high $\mathrm{NO}_{x}^{+}$ratio cannot be separated, resulting in an overestimation of pON. Lastly, HR-AMS only measures submicron non-refractory pON, which might also underestimate $\mathrm{pON}$ in ambient air.

Overall, the pON estimated from the TD-AMS method correlated well with those from PMF and $\mathrm{NO}_{x}$ methods, yet it has advantages in estimating pON in an anthropogenically dominant environment. Particularly, we found that $R_{\mathrm{ON}}$ varied differently between day and night and between clean and polluted episodes, highlighting different pON compounds from different chemical pathways and sources. Our estimation showed higher mass concentrations of $\mathrm{NO}_{3 \text {,org }}$ in summer than in winter $\left(1.8 \mathrm{vs} .1 .0 \mathrm{\mu g} \mathrm{m}^{-3}\right)$, as well as a greater contribution of pON to OA ( $27.5 \%$ vs. $14.8 \%)$, indicating more pON formation in a biogenically and anthropogenically mixed environment. In addition, the $\mathrm{NO}_{3}$, org loadings at the rural site $\left(1.9 \mu \mathrm{g} \mathrm{m}^{-3}\right)$ were higher than that in Beijing due to higher primary emissions and gaseous precursors during wintertime.

Data availability. The data in this study are available from the authors upon request (sunyele@mail.iap.ac.cn).

Supplement. The supplement related to this article is available online at: https://doi.org/10.5194/amt-14-3693-2021-supplement.

Author contributions. YS and WeX designed the research. WeX, CC, YQ, CX, WaX and NM conducted the measurements. WeX, MT, CC and YQ analyzed the data. MT, DRW and NLN reviewed and commented on the paper. WeX and YS wrote the paper.

Competing interests. The authors declare that they have no conflict of interest.

Financial support. This research has been supported by the China Postdoctoral Science Foundation (grant no. 2020M670421), the National Oceanic and Atmospheric Administration (grant no. NA18OAR4310112) and the National Science Foundation (grant no. CAREER AGS-1555034).

Review statement. This paper was edited by Mingjin Tang and reviewed by two anonymous referees.

\section{References}

Berkemeier, T., Takeuchi, M., Eris, G., and Ng, N. L.: Kinetic modeling of formation and evaporation of secondary organic aerosol from $\mathrm{NO}_{3}$ oxidation of pure and mixed monoterpenes, Atmos. Chem. Phys., 20, 15513-15535, https://doi.org/10.5194/acp-2015513-2020, 2020.

Blando, J. D., Porcja, R. J., Li, T. H., Bowman, D., Lioy, P. J., and Turpin, B. J.: Secondary formation and the Smoky Mountain organic aerosol: An examination of aerosol polarity and functional group composition during SEAVS, Environ. Sci. Technol., 32, 604-613, 1998.

Boyd, C. M., Sanchez, J., Xu, L., Eugene, A. J., Nah, T., Tuet, W. Y., Guzman, M. I., and Ng, N. L.: Secondary organic aerosol formation from the $\beta$-pinene $+\mathrm{NO}_{3}$ system: effect of humidity and peroxy radical fate, Atmos. Chem. Phys., 15, 7497-7522, https://doi.org/10.5194/acp-15-7497-2015, 2015.

Boyd, C. M., Nah, T., Xu, L., Berkemeier, T., and $\mathrm{Ng}$, N. L.: Secondary Organic Aerosol (SOA) from Nitrate Radical Oxidation of Monoterpenes: Effects of Temperature, Dilution, and Humidity on Aerosol Formation, Mixing, and Evaporation, Environ. Sci. Technol., 51, 7831-7841, https://doi.org/10.1021/acs.est.7b01460, 2017.

Bruns, E. A., Perraud, V. R., Zelenyuk, A., Ezell, M. J., Johnson, S. N., Yu, Y., Imre, D., Finlayson-Pitts, B. J., and Alexander, M. L.: Comparison of FTIR and Particle Mass Spectrometry for the Measurement of Particulate Organic Nitrates, Environ. Sci. Technol., 44, 1056-1061, https://doi.org/10.1021/es9029864, 2010.

Canagaratna, M. R., Jimenez, J. L., Kroll, J. H., Chen, Q., Kessler, S. H., Massoli, P., Hildebrandt Ruiz, L., Fortner, E., Williams, L. R., Wilson, K. R., Surratt, J. D., Donahue, N. M., Jayne, J. T., and Worsnop, D. R.: Elemental ratio measurements of organic compounds using aerosol mass spectrometry: characterization, improved calibration, and implications, Atmos. Chem. Phys., 15, 253-272, https://doi.org/10.5194/acp-15-253-2015, 2015.

Chen, C., Li, Z., Sun, J., Xu, W., Qiu, Y., Xie, C., He, Y., Li, Y., Li, J., Fu, P., Wang, Z., Worsnop, D. R., and Sun, Y.: Characterization of submicron aerosol in North China Plain (NCP), in preparation, 2021.

Dai, Q., Schulze, B. C., Bi, X., Bui, A. A. T., Guo, F., Wallace, H. W., Sanchez, N. P., Flynn, J. H., Lefer, B. L., Feng, Y., and Griffin, R. J.: Seasonal differences in formation processes of oxidized organic aerosol near Houston, TX, Atmos. Chem. Phys., 19, 9641-9661, https://doi.org/10.5194/acp-19-9641-2019, 2019.

Day, D. A., Wooldridge, P. J., Dillon, M. B., Thornton, J. A., and Cohen, R. C.: A thermal dissociation laser-induced fluorescence instrument for in situ detection of $\mathrm{NO}_{2}$, peroxy nitrates, alkyl nitrates, and $\mathrm{HNO}_{3}$, J. Geophys. Res.-Atmos., 107, ACH 4-1ACH 4-14, https://doi.org/10.1029/2001jd000779, 2002.

Farmer, D. K., Matsunaga, A., Docherty, K. S., Surratt, J. D., Seinfeld, J. H., Ziemann, P. J., and Jimenez, J. L.: Response of an aerosol mass spectrometer to organonitrates and organosulfates and implications for atmospheric chemistry, Proc. Natl. Acad. Sci. USA, 107, 6670-6675, https://doi.org/10.1073/pnas.0912340107, 2010.

Fry, J. L., Kiendler-Scharr, A., Rollins, A. W., Wooldridge, P. J., Brown, S. S., Fuchs, H., Dubé, W., Mensah, A., dal Maso, M., Tillmann, R., Dorn, H.-P., Brauers, T., and Cohen, R. C.: Organic nitrate and secondary organic aerosol yield from $\mathrm{NO}_{3}$ oxidation of $\beta$-pinene evaluated using a gas-phase kinet- 
ics/aerosol partitioning model, Atmos. Chem. Phys., 9, 14311449, https://doi.org/10.5194/acp-9-1431-2009, 2009.

Fry, J. L., Draper, D. C., Zarzana, K. J., Campuzano-Jost, P., Day, D. A., Jimenez, J. L., Brown, S. S., Cohen, R. C., Kaser, L., Hansel, A., Cappellin, L., Karl, T., Hodzic Roux, A., Turnipseed, A., Cantrell, C., Lefer, B. L., and Grossberg, N.: Observations of gas- and aerosol-phase organic nitrates at BEACHON-RoMBAS 2011, Atmos. Chem. Phys., 13, 85858605, https://doi.org/10.5194/acp-13-8585-2013, 2013.

Huffman, J. A., Ziemann, P. J., Jayne, J. T., Worsnop, D. R., and Jimenez, J. L.: Development and Characterization of a FastStepping/Scanning Thermodenuder for Chemically-Resolved Aerosol Volatility Measurements, Aerosol Sci. Tech., 42, 395407, 2008

Huffman, J. A., Docherty, K. S., Aiken, A. C., Cubison, M. J., Ulbrich, I. M., DeCarlo, P. F., Sueper, D., Jayne, J. T., Worsnop, D. R., Ziemann, P. J., and Jimenez, J. L.: Chemically-resolved aerosol volatility measurements from two megacity field studies, Atmos. Chem. Phys., 9, 7161-7182, https://doi.org/10.5194/acp9-7161-2009, 2009.

Jayne, J. T., Leard, D. C., Zhang, X., Davidovits, P., Smith, K. A., Kolb, C. E., and Worsnop, D. R.: Development of an aerosol mass spectrometer for size and composition analysis of submicron particles, Aerosol Sci. Tech., 33, 49-70, 2000.

Jordan, C., Ziemann, P., Griffin, R., Lim, Y., Atkinson, R., and Arey, J.: Modeling SOA formation from $\mathrm{OH}$ reactions with $\mathrm{C} 8-\mathrm{C} 17 \mathrm{n}-$ alkanes, Atmos. Environ., 42, 8015-8026, 2008.

Kiendler-Scharr, A., Mensah, A. A., Friese, E., Topping, D., Nemitz, E., Prevot, A. S. H., Aijala, M., Allan, J., Canonaco, F., Canagaratna, M., Carbone, S., Crippa, M., Dall Osto, M., Day, D. A., De Carlo, P., Di Marco, C. F., Elbern, H., Eriksson, A., Freney, E., Hao, L., Herrmann, H., Hildebrandt, L., Hillamo, R., Jimenez, J. L., Laaksonen, A., McFiggans, G., Mohr, C., O’Dowd, C., Otjes, R., Ovadnevaite, J., Pandis, S. N., Poulain, L., Schlag, P., Sellegri, K., Swietlicki, E., Tiitta, P., Vermeulen, A., Wahner, A., Worsnop, D., and Wu, H. C.: Ubiquity of organic nitrates from nighttime chemistry in the European submicron aerosol, Geophys. Res. Lett., 43, 7735-7744, https://doi.org/10.1002/2016gl069239, 2016.

Kortelainen, A., Hao, L. Q., Tiitta, P., Jaatinen, A., Miettinen, P., Kulmala, M., Smith, J. N., Laaksonen, A., Worsnop, D. R., and Virtanen, A.: Sources of particulate organic nitrates in the boreal forest in Finland, Boreal Environ. Res., 22, 13-26, 2017.

Kuang, Y., He, Y., Xu, W., Yuan, B., Zhang, G., Ma, Z., Wu, C., Wang, C., Wang, S., Zhang, S., Tao, J., Ma, N., Su, H., Cheng, Y., Shao, M., and Sun, Y.: Photochemical Aqueous-Phase Reactions Induce Rapid Daytime Formation of Oxygenated Organic Aerosol on the North China Plain, Environ. Sci. Technol., 54, 3849-3860, https://doi.org/10.1021/acs.est.9b06836, 2020.

Lee, A. K. Y., Adam, M. G., Liggio, J., Li, S.-M., Li, K., Willis, M. D., Abbatt, J. P. D., Tokarek, T. W., Odame-Ankrah, C. A., Osthoff, H. D., Strawbridge, K., and Brook, J. R.: A large contribution of anthropogenic organo-nitrates to secondary organic aerosol in the Alberta oil sands, Atmos. Chem. Phys., 19, 12209 12219, https://doi.org/10.5194/acp-19-12209-2019, 2019.

Lee, B. H., Lopez-Hilfiker, F. D., Mohr, C., Kurten, T., Worsnop, D. R., and Thornton, J. A.: An iodide-adduct high-resolution timeof-flight chemical-ionization mass spectrometer: application to atmospheric inorganic and organic compounds, Environ. Sci.
Technol., 48, 6309-6317, https://doi.org/10.1021/es500362a, 2014.

Lee, B. H., Mohr, C., Lopez-Hilfiker, F. D., Lutz, A., Hallquist, M., Lee, L., Romer, P., Cohen, R. C., Iyer, S., Kurtén, T., Hu, W., Day, D. A., Campuzano-Jost, P., Jimenez, J. L., Xu, L., Ng, N. L., Guo, H., Weber, R. J., Wild, R. J., Brown, S. S., Koss, A., de Gouw, J., Olson, K., Goldstein, A. H., Seco, R., Kim, S., McAvey, K., Shepson, P. B., Starn, T., Baumann, K., Edgerton, E. S., Liu, J., Shilling, J. E., Miller, D. O., Brune, W., Schobesberger, S., D'Ambro, E. L., and Thornton, J. A.: Highly functionalized organic nitrates in the southeast United States: Contribution to secondary organic aerosol and reactive nitrogen budgets, Proc. Natl. Acad. Sci. USA, 113, 1516-1521, https://doi.org/10.1073/pnas.1508108113, 2016.

Lee, L., Wooldridge, P. J., deGouw, J., Brown, S. S., Bates, T. S., Quinn, P. K., and Cohen, R. C.: Particulate organic nitrates observed in an oil and natural gas production region during wintertime, Atmos. Chem. Phys., 15, 9313-9325, https://doi.org/10.5194/acp-15-9313-2015, 2015.

Li, K., Liggio, J., Han, C., Liu, Q. F., Moussa, S. G., Lee, P., and Li, S. M.: Understanding the Impact of High-NOx Conditions on the Formation of Secondary Organic Aerosol in the Photooxidation of Oil Sand-Related Precursors, Environ. Sci. Technol., 53, 14420-14429, https://doi.org/10.1021/acs.est.9b05404, 2019.

Li, W., Liu, L., Zhang, J., Xu, L., Wang, Y., Sun, Y., and Shi, Z.: Microscopic Evidence for Phase Separation of Organic Species and Inorganic Salts in Fine Ambient Aerosol Particles, Environ. Sci. Technol., 55, 2234-2242, https://doi.org/10.1021/acs.est.0c02333, 2021.

Lim, Y. B. and Ziemann, P. J.: Chemistry of secondary organic aerosol formation from $\mathrm{OH}$ radical-initiated reactions of linear, branched, and cyclic alkanes in the presence of $\mathrm{NO}_{x}$, Aerosol Sci. Tech., 43, 604-619, 2009.

Liu, L., Zhang, J., Zhang, Y., Wang, Y., Xu, L., Yuan, Q., Liu, D., Sun, Y., Fu, P., Shi, Z., and Li, W.: Persistent residential burningrelated primary organic particles during wintertime hazes in North China: insights into their aging and optical changes, Atmos. Chem. Phys., 21, 2251-2265, https://doi.org/10.5194/acp21-2251-2021, 2021.

Liu, S., Shilling, J. E., Song, C., Hiranuma, N., Zaveri, R. A., and Russell, L. M.: Hydrolysis of Organonitrate Functional Groups in Aerosol Particles, Aerosol Sci. Tech., 46, 1359-1369, https://doi.org/10.1080/02786826.2012.716175, 2012.

Liu, Y., Song, M., Liu, X., Zhang, Y., Hui, L., Kong, L., Zhang, Y., Zhang, C., Qu, Y., An, J., Ma, D., Tan, Q., and Feng, M.: Characterization and sources of volatile organic compounds (VOCs) and their related changes during ozone pollution days in 2016 in Beijing, China, Environ. Pollut., 257, 113599, https://doi.org/10.1016/j.envpol.2019.113599, 2020.

Lopez-Hilfiker, F. D., Mohr, C., Ehn, M., Rubach, F., Kleist, E., Wildt, J., Mentel, Th. F., Lutz, A., Hallquist, M., Worsnop, D., and Thornton, J. A.: A novel method for online analysis of gas and particle composition: description and evaluation of a Filter Inlet for Gases and AEROsols (FIGAERO), Atmos. Meas. Tech., 7, 983-1001, https://doi.org/10.5194/amt-7-983-2014, 2014.

Matsunaga, A. and Ziemann, P. J.: Yields of $\beta$-hydroxynitrates, dihydroxynitrates, and trihydroxynitrates formed from $\mathrm{OH}$ radicalinitiated reactions of 2-methyl-1-alkenes, Proc. Natl. Acad. Sci. USA, 107, 6664-6669, 2010. 
Middlebrook, A. M., Bahreini, R., Jimenez, J. L., and Canagaratna, M. R.: Evaluation of Composition-Dependent Collection Efficiencies for the Aerodyne Aerosol Mass Spectrometer using Field Data, Aerosol Sci. Tech., 46, 258-271, https://doi.org/10.1080/02786826.2011.620041, 2012.

Ng, N. L., Brown, S. S., Archibald, A. T., Atlas, E., Cohen, R. C., Crowley, J. N., Day, D. A., Donahue, N. M., Fry, J. L., Fuchs, H., Griffin, R. J., Guzman, M. I., Herrmann, H., Hodzic, A., Iinuma, Y., Jimenez, J. L., Kiendler-Scharr, A., Lee, B. H., Luecken, D. J., Mao, J., McLaren, R., Mutzel, A., Osthoff, H. D., Ouyang, B., Picquet-Varrault, B., Platt, U., Pye, H. O. T., Rudich, Y., Schwantes, R. H., Shiraiwa, M., Stutz, J., Thornton, J. A., Tilgner, A., Williams, B. J., and Zaveri, R. A.: Nitrate radicals and biogenic volatile organic compounds: oxidation, mechanisms, and organic aerosol, Atmos. Chem. Phys., 17, 2103-2162, https://doi.org/10.5194/acp-17-2103-2017, 2017.

O’Brien, J. M., Shepson, P. B., Muthuramu, K., Hao, C., Niki, H., Hastie, D. R., Taylor, R., and Roussel, P. B.: Measurements of alkyl and multifunctional organic nitrates at a rural site in Ontario, J. Geophys. Res.-Atmos., 100, 22795-22804, https://doi.org/10.1029/94jd03247, 1995.

Perring, A., Pusede, S., and Cohen, R.: An observational perspective on the atmospheric impacts of alkyl and multifunctional nitrates on ozone and secondary organic aerosol, Chem. Rev., 113, 58485870, 2013.

Qiao, Z., Li-Ming, C., Meng-Xue, T., Xiao-Feng, H., Eri, S., and He, L. Y.: Characterization of organic aerosol at a rural site in North China Plain: sources, volatility and organonitrates, Adv. Atmos. Sci., https://doi.org/10.1007/s00376-020-0127-2, in press, 2021.

Ramasamy, S., Nakayama, T., Imamura, T., Morino, Y., Kajii, Y., and Sato, K.: Investigation of dark condition nitrate radical- and ozone-initiated aging of toluene secondary organic aerosol: Importance of nitrate radical reactions with phenolic products, Atmos. Environ., 219, 117049, https://doi.org/10.1016/j.atmosenv.2019.117049, 2019.

Rindelaub, J. D., McAvey, K. M., and Shepson, P. B.: The photochemical production of organic nitrates from alpha-pinene and loss via acid-dependent particle phase hydrolysis, Atmos. Environ., 100, 193-201, https://doi.org/10.1016/j.atmosenv.2014.11.010, 2015.

Romer Present, P. S., Zare, A., and Cohen, R. C.: The changing role of organic nitrates in the removal and transport of NOx, Atmos. Chem. Phys., 20, 267-279, https://doi.org/10.5194/acp-20-2672020, 2020.

Sadanaga, Y., Takaji, R., Ishiyama, A., Nakajima, K., Matsuki, A., and Bandow, H.: Thermal dissociation cavity attenuated phase shift spectroscopy for continuous measurement of total peroxy and organic nitrates in the clean atmosphere, Rev. Sci. Instrum., 87, 074102, https://doi.org/10.1063/1.4958167, 2016.

Sheng, J., Wang, F., Li, X., Ma, Z., Liu, Q., Zhao, D., Huang, M., and Ding, D.: The temporal variation and photochemical characters of VOCs in summer and winter of Beijing based on PTR-TOF-MS, Huanjing Huaxue-Environmental Chemistry, 38, 1590-1599, https://doi.org/10.7524/j.issn.02546108.2018092601, 2019.

Sun, Y., He, Y., Kuang, Y., Xu, W., Song, S., Ma, N., Tao, J., Cheng, P., Wu, C., Su, H., Cheng, Y., Xie, C., Chen, C., Lei, L., Qiu, Y., Fu, P., Croteau, P., and Worsnop, D. R.: Chemical Differences
Between $\mathrm{PM}_{1}$ and $\mathrm{PM}_{2.5}$ in Highly Polluted Environment and Implications in Air Pollution Studies, Geophys. Res. Lett., 47, e2019GL086288, https://doi.org/10.1029/2019g1086288, 2020.

Sun, Y. L., Zhang, Q., Schwab, J. J., Yang, T., Ng, N. L., and Demerjian, K. L.: Factor analysis of combined organic and inorganic aerosol mass spectra from high resolution aerosol mass spectrometer measurements, Atmos. Chem. Phys., 12, 8537-8551, https://doi.org/10.5194/acp-12-8537-2012, 2012.

Sun, Y. L., Wang, Z. F., Fu, P. Q., Yang, T., Jiang, Q., Dong, H. B., Li, J., and Jia, J. J.: Aerosol composition, sources and processes during wintertime in Beijing, China, Atmos. Chem. Phys., 13, 4577-4592, https://doi.org/10.5194/acp-13-4577-2013, 2013.

Takeuchi, M. and Ng, N. L.: Chemical composition and hydrolysis of organic nitrate aerosol formed from hydroxyl and nitrate radical oxidation of $\alpha$-pinene and $\beta$-pinene, Atmos. Chem. Phys., 19, 12749-12766, https://doi.org/10.5194/acp-19-127492019, 2019.

Thieser, J., Schuster, G., Schuladen, J., Phillips, G. J., Reiffs, A., Parchatka, U., Pöhler, D., Lelieveld, J., and Crowley, J. N.: A two-channel thermal dissociation cavity ring-down spectrometer for the detection of ambient $\mathrm{NO}_{2}, \mathrm{RO}_{2} \mathrm{NO}_{2}$ and $\mathrm{RONO}_{2}$, Atmos. Meas. Tech., 9, 553-576, https://doi.org/10.5194/amt-9553-2016, 2016.

Xu, L., Guo, H. Y., Boyd, C. M., Klein, M., Bougiatioti, A., Cerully, K. M., Hite, J. R., Isaacman-VanWertz, G., Kreisberg, N. M., Knote, C., Olson, K., Koss, A., Goldstein, A. H., Hering, S. V., de Gouw, J., Baumann, K., Lee, S. H., Nenes, A., Weber, R. J., and $\mathrm{Ng}$, N. L.: Effects of anthropogenic emissions on aerosol formation from isoprene and monoterpenes in the southeastern United States Proc. Natl. Acad. Sci. USA, 112, E4509-E4509, https://doi.org/10.1073/pnas.1512279112, 2015a.

Xu, L., Suresh, S., Guo, H., Weber, R. J., and Ng, N. L.: Aerosol characterization over the southeastern United States using high-resolution aerosol mass spectrometry: spatial and seasonal variation of aerosol composition and sources with a focus on organic nitrates, Atmos. Chem. Phys., 15, 7307-7336, https://doi.org/10.5194/acp-15-7307-2015, 2015 b.

Xu, L., Williams, L. R., Young, D. E., Allan, J. D., Coe, H., Massoli, P., Fortner, E., Chhabra, P., Herndon, S., Brooks, W. A., Jayne, J. T., Worsnop, D. R., Aiken, A. C., Liu, S., Gorkowski, K., Dubey, M. K., Fleming, Z. L., Visser, S., Prévôt, A. S. H., and Ng, N. L.: Wintertime aerosol chemical composition, volatility, and spatial variability in the greater London area, Atmos. Chem. Phys., 16, 1139-1160, https://doi.org/10.5194/acp-16-1139-2016, 2016.

Xu, W., Han, T., Du, W., Wang, Q., Chen, C., Zhao, J., Zhang, Y., Li, J., Fu, P., Wang, Z., Worsnop, D. R., and Sun, Y.: Effects of Aqueous-Phase and Photochemical Processing on Secondary Organic Aerosol Formation and Evolution in Beijing, China, Environ. Sci. Technol., 51, 762-770, https://doi.org/10.1021/acs.est.6b04498, 2017a.

Xu, W., Sun, Y., Wang, Q., Du, W., Zhao, J., Ge, X., Han, T., Zhang, Y., Zhou, W., Li, J., Fu, P., Wang, Z., and Worsnop, D. R.: Seasonal Characterization of Organic Nitrogen in Atmospheric Aerosols Using High Resolution Aerosol Mass Spectrometry in Beijing, China, ACS Earth and Space Chemistry, 1, 673-682, https://doi.org/10.1021/acsearthspacechem.7b00106, 2017b.

Xu, W., He, Y., Qiu, Y., Chen, C., Xie, C., Lei, L., Li, Z., Sun, J., Li, J., Fu, P., Wang, Z., Worsnop, D. R., and Sun, Y.: Mass spectral characterization of primary emissions and implications in source 
apportionment of organic aerosol, Atmos. Meas. Tech., 13, 3205-3219, https://doi.org/10.5194/amt-13-3205-2020, 2020.

Xu, W., Chen, C., Qiu, Y., Li, Y., Zhang, Z., Karnezi, E., Pandis, S. N., Xie, C., Li, Z., Sun, J., Ma, N., Xu, W., Fu, P., Wang, Z., Zhu, J., Worsnop, D. R., Ng, N. L., and Sun, Y.: Organic aerosol volatility and viscosity in the North China Plain: contrast between summer and winter, Atmos. Chem. Phys., 21, 5463-5476, https://doi.org/10.5194/acp-21-5463-2021, 2021.

Xu, W., Xie, C., Karnezi, E., Zhang, Q., Wang, J., Pandis, S. N., Ge, X., Zhang, J., An, J., Wang, Q., Zhao, J., Du, W., Qiu, Y., Zhou, W., He, Y., Li, Y., Li, J., Fu, P., Wang, Z., Worsnop, D. R., and Sun, Y.: Summertime aerosol volatility measurements in Beijing, China, Atmos. Chem. Phys., 19, 10205-10216, https://doi.org/10.5194/acp-19-10205-2019, 2019.

Yu, K., Zhu, Q., Du, K., and Huang, X.-F.: Characterization of nighttime formation of particulate organic nitrates based on high-resolution aerosol mass spectrometry in an urban atmosphere in China, Atmos. Chem. Phys., 19, 5235-5249, https://doi.org/10.5194/acp-19-5235-2019, 2019.
Zhang, J. K., Cheng, M. T., Ji, D. S., Liu, Z. R., Hu, B., Sun, Y., and Wang, Y. S.: Characterization of submicron particles during biomass burning and coal combustion periods in Beijing, China, Sci. Total Environ., 562, 812-821, https://doi.org/10.1016/j.scitotenv.2016.04.015, 2016.

Zhou, W., Xu, W., Kim, H., Zhang, Q., Fu, P., Worsnop, D. R., and Sun, Y.: A review of aerosol chemistry in Asia: insights from aerosol mass spectrometer measurements, Environ. Sci.-Proc. Imp., 22, 1616-1653, https://doi.org/10.1039/d0em00212g, 2020.

Zhu, Q., He, L.-Y., Huang, X.-F., Cao, L.-M., Gong, Z.-H., Wang, C., Zhuang, X., and Hu, M.: Atmospheric aerosol compositions and sources at two national background sites in northern and southern China, Atmos. Chem. Phys., 16, 10283-10297, https://doi.org/10.5194/acp-16-10283-2016, 2016. 